\title{
Review
}

\section{Neonatal mass screening for 21-hydroxylase deficiency}

\author{
Toshihiro Tajima ${ }^{1 \#}$, and Masaru Fukushi \\ ${ }^{1}$ Department of Pediatrics, Hokkaido University School of Medicine, Sapporo, Japan \\ ${ }^{2}$ Sapporo IDL, Sapporo, Japan \\ \# Present: Jichi Children's Medical Center Tochigi, Shimotsuke, Japan
}

\begin{abstract}
Congenital adrenal hyperplasia(CAH)due to 21-hydroxylase deficiency (21-OHD) is an inherited autosomal recessive disorder. Its incidence is 1 in 10,000 to 20,000 worldwide. This disease shows phenotypic differences, and it is divided into three forms i.e., the salt wasting (SW), simple virilizing (SV), and nonclassic (NC) forms. The most severe form of SW manifests in the first months of life with life-threatening adrenal insufficiency, leading to death. To prevent death by adrenal insufficiency in neonates with the SW form and wrong gender assignment of 46,XX female patients with SW and SV, neonatal mass screening of 21-OHD is performed in several countries including Japan. However, the positive predictive value (PPV) remains low, especially in preterm infants. To reduce the false positive rate and increase the PPV, liquid chromatography followed by tandem mass spectrometry (LC-MS/MS) as a second-tier test may be useful. In this review, the current knowledge on neonatal mass screening of 21-OHD is summarized.
\end{abstract}

Key words: 21-hydroxylase deficiency, neonatal screening, liquid chromatography followed by tandem mass spectrometry (LC-MS/MS)

\section{Introduction}

Congenital adrenal hyperplasia $(\mathrm{CAH})$ is a group of genetically inherited enzymatic defects of biosynthesis of cortisol and accumulating intermediate precursors. The most common form of CAH is 21-hydroxylase deficiency (21-OHD) (1-5), which affects about 1 in 18,000 worldwide. 21-OHD is classified into three forms according

Received: June 9, 2015

Accepted: August 13, 2015

Corresponding author: Toshihiro Tajima, Jichi Children's Medical Center Tochigi, 3311-1 Yakushiji, Shimotsuke-shi, Tochigi 329-0498, Japan

E-mail: t-tajima@jichi.ac.jp

This is an open-access article distributed under the terms of the Creative Commons Attribution Non-Commercial No Derivatives (by-nc-nd) License <http://creativecommons.org/ licenses/by-nc-nd/4.0/>. to the severity of the disease. The most severe form is the salt-wasting (SW) form. In the SW and simple virilizing (SV) forms, affected female neonates present with virilized external genitalia. The nonclassic (NC) form can manifest with hyperandrogenism later in life (3-5). The SW form accounts for approximately $70-80 \%$ of all cases of $21-\mathrm{OHD}(1,3,5)$. In children with the SW form, a life-threatening salt-wasting crisis occurs in the second or third week of life.

Ambiguous genitalia at birth or salt-wasting symptoms such as failure to thrive, and vomiting and skin pigmentation during the neonatal period can lead to the suspicion of 21-OHD. Elevated 17-hydroxyprogesterone (17-OHP) is the best marker for the diagnosis of 21-OHD (3, $5)$. In addition, patients with the $\mathrm{SW}$ form show elevated plasma renin activity or an elevated 
plasma renin.

As the initial treatment, a high dose of hydrocortisone is administered to rapidly suppress adrenal hyperplasia and excess adrenal androgen (5). Thereafter, the dose of hydrocortisone is reduced to a maintenance dose, and lifelong treatment is necessary (5). In infants with the SW form, $9 a$-fludrocortisone is required in addition to hydrocortisone $(3,5)$. In childhood, the main targets of treatment of 21-OHD are as follows: 1) normal physical growth, 2) normal development of secondary sex characteristics, and 3) avoidance of adrenal crisis $(1-3,5)$. After reaching adulthood, the transition to an adult endocrinologist is required $(3,5-7)$. As the relationship between metabolic abnormalities and glucocorticoid dose in adult patients with 21-OHD has recently been reported in several studies (8-11), pediatricians who care for 21-OHD patients should avoid overdose of glucocorticoid.

\section{Newborn Mass Screening (MS) for CAH}

The purposes of MS for CAH are prevention of death caused by adrenal insufficiency in neonates with the SW form and gender misassignment of 46,XX female neonates with the SW and SV forms (3, 5, 12-14). MS for CAH was first reported in 1977 (15), and since then, MS for CAH has been implemented in at least 30 countries $(9,14$, 16-23). However, CAH screening is associated with a high false positive rate (FPR) and low positive predictive value (PPV), especially in preterm infants $(3,5,8,24-26)$. Moreover, as affected girls with the SW and SV forms show virilized genitalia at birth, clinical diagnosis is thought to be easy (26). Based on these points of view, several countries do not perform $\mathrm{MS}$ for CAH $(27,28)$.

In 2012, the efficiency of neonatal screening for CAH in France from 1996 to 2003 was reported (26). In their study, a total of 6,012,798 neonates were screened and 15,407 were positive on screening for CAH. However, among these cases, only 370 were ultimately diagnosed as having $\mathrm{CAH}$. Among them, family history led to the diagnosis of CAH in 74 infants, and in 96 girls with $\mathrm{CAH}$, ambiguous genitalia were identified during neonatal examination. In addition, 13 boys were clinically diagnosed as having $\mathrm{CAH}$ before obtaining the results of MS. Therefore, in these 183 patients (about half of the total number of patients with $\mathrm{CAH}$ ), MS for $\mathrm{CAH}$ was not beneficial. Moreover, among 38 premature neonates with positive screening results, $\mathrm{MS}$ was useful for the diagnosis of CAH in 13 infants, among whom only 6 had the severe SW form. During this period, the sensitivity of MS for CAH was $93.5 \%$, and the PPV was $2.3 \%$. Furthermore, the PPV in preterm infants was only $0.4 \%$.

One of the rationales for MS for $\mathrm{CAH}$ is to prevent the death of neonates. In their study, Coulm et al. analyzed mortality rates of neonates due to adrenal insufficiency in children younger than $1 \mathrm{yr}$ of age from 1979 to 2007 (26). The mortality rate of adrenal diseases from 1979 to 1984 was 0.10 per 100,000 births. From 1985 to 1990 , it increased to 0.20 per 100,000 births. From 1991 to 1995 , it decreased to about 0.09 per 100,000 births, and from 1991 to 1995 , it was about 0.08 per 100,000 births. Therefore, most of the decrease was observed in 1991-1995. As nationwide MS for CAH began in 1996 in France, decrease of the mortality rate was not associated with the screening.

In the UK, CAH is not included in newborn mass screening. Khalid et al. (28) reported clinical features of congenital adrenal hyperplasia in the UK. Approximately $90 \%$ of CAH patients were diagnosed before one year of age. Most girls were diagnosed by virilization of external genitalia, and about $20 \%$ of patients with $\mathrm{CAH}$ presented with salt-wasting crisis on or after 14 days of age. Therefore, MS for CAH could have prevented salt-wasting crisis in these $20 \%$ of patients with CAH.

Gidlof et al. (22) reported the results of the nationwide MS for CAH in Sweden over a 26-yr period, which is the longest study 
period so far. They concluded that MS for $\mathrm{CAH}$ is highly effective in detecting SW and therefore in reducing mortality.During the 26yr period, almost all infants born from 1986 to 2011 (2,737,932 newborns) were subjected to screening. A total of 143 patients with SW were identified. The sensitivity of MS for CAH was $84.3 \%$, and the specificity was $99.9 \%$. The total recall rate was $0.06 \%$. However, the recall rate in preterm infants $(0.57 \%)$ was significantly higher than that in term infants $(0.03 \%)$. The PPV in term infants was $25 \%$. On the other hand, the PPV in preterm infants was $1.4 \%$ despite gestational age-related cutoff levels.

The difference in opinion regarding MS for CAH may be related to the way of thinking about prevention of SW crisis, health administration, and finance of health administration.

\section{Liquid Chromatography-tandem Mass Spectrometry (LC-MS/MS) in MS for CAH}

LC-MS/MS is now being incorporated in newborn screening laboratories in several countries. A method of performing a steroidprofiling assay for simultaneous analysis of 17-hydroxyprogesterone, androstenedione (4$\mathrm{AD}), 21$-deoxycortisol (21-DOF), 11-deoxycortisol (11-DOF) and cortisol has been reported (29-36). Performance of a steroid-profiling assay by LCMS/MS as a second-tier test in MS for CAH may avoid unnecessary recalls, reduce the FPR and increase the PPV.

Minnesota, USA a two-tier protocol in which a second-tier test was performed using LC-MS/MS to measure the levels of 17-OHP, 4-AD, and cortisol simultaneously in blood filter papers was started in 2004, and the efficiency of the second-tier steroid test using LC-MS/MS has been reported (33). From 1999 to 2004, a one-tier protocol had been used. In the one-tier protocol, the 17-OHP level was measured by immunoassay, and weight-based cutoff values were employed. From 2004, following two-tier screening protocol was employed: If the 17-OHP level was above the cutoff level in the first-tier test using an immunoassay, the filter paper was automatically analyzed by LC-MS/MS as a second-tier test. The cutoff levels of the blood 17-OHP level and the ratio of (17-OHP+4-AD)/ cortisol in the two-tier test are summarized in Table 1. From 2004 to 2008, various cutoff values and analytes were used in the second-tier steroidprofiling assay. From 2008, gender-specific reference ranges of 17-OHP were used because girls had lower 17-OHP levels $(37,38)$.

A negative result in the second-tier test [either a normal 17-OHP level or a normal ratio of (17-OHP+4-AD)/cortisol] was considered negative. If the second-tier test was positive [both the 17-OHP level and the ratio of (17-OHP+4$\mathrm{AD}) /$ cortisol were above the cutoff], the result was presumed to be positive, and the infant was subjected to medical examination.

When using the two-tier protocol, the false negative rate and FPR unexpectedly increased to $32.4 \%$ (one-tier protocol, $15.4 \%$ ) and $0.065 \%$ (one-tier protocol, 0.057\%), respectively, and the PPV decreased to 8\% (one-tier screening, 9.5\%), although these changes were not statistically significant. However, the two-tier protocol was effective in reducing the recall for another heel prick. An average of 355 infants per year were recalled in the one-tier protocol, but an average of 30 infants per year were recalled in the two-tier protocol.

In the two-tier protocol for MS, eleven infants were missed. Of them, 3 patients had the SW form, and 8 patients had the SV form. These cases were missed for the following reasons. The blood 17-OHP levels in 7 infants were below the cutoff in the first-tier test. The other four cases showed an increased 17-OHP level in the firsttier test, but the 17-OHP level in one of these four infants was below the cutoff level in the second-tier test. In the remaining three cases, the blood 17-OHP levels were above the cutoff in the second-tier test, but the ratio of (17-OHP $+4 \mathrm{AD}$ )/cortisol was below the cutoff, and the results of the second-tier tests were presumed to 
Table 1 Cutoff levels of LC-MS/MS in the second-tier test

\begin{tabular}{|c|c|c|c|c|}
\hline & $\begin{array}{l}\text { 17-OHP } \\
\text { (ng/ml) }\end{array}$ & $\begin{array}{c}\text { 17-OHP+4AD/ } \\
\text { cortisol }\end{array}$ & $\begin{array}{c}\text { 17-OHP } \\
\text { (girls) (ng/ml) }\end{array}$ & $\begin{array}{c}\text { 17-OHP } \\
\text { (boys) (ng/ml) }\end{array}$ \\
\hline $\begin{array}{l}\text { Minnesota* (ref. 32) } \\
\text { Year } 2004 \text { to } 2006 \\
\text { Year } 2006 \text { to } 2008 \\
\text { Year } 2008 \text { to } 2012\end{array}$ & $\begin{array}{l}>12.5 \\
>10.2\end{array}$ & $\begin{array}{l}>3.75 \\
>2.5 \\
>2.5\end{array}$ & $>4.0$ & $>7.0$ \\
\hline $\begin{array}{l}\text { Utah* (ref. 33) } \\
\text { Year } 2007 \text { to } 2008\end{array}$ & $>12.5$ & $>1.0$ & & \\
\hline $\begin{array}{l}\text { Sapporo \# (ref. 36) } \\
\text { Year } 2011 \text { to } 2012 \\
\geq 37 \text { wk of gestation \# } \\
\geq 37 \text { wk of gestation \# } \\
<37 \text { wk of gestation \# } \\
<37 \text { wk of gestation \# }\end{array}$ & $\begin{array}{l}\geq 4 \\
\geq 3 \\
\geq 6 \\
\geq 5\end{array}$ & $\begin{array}{l}\geq 0.2 \\
\geq 0.2\end{array}$ & & \\
\hline $\begin{array}{l}\text { * In the studies conduct } \\
17 \text {-OHP was adopted in } \\
\text { adjusted cutoff levels of } \\
\text { of the second-tier test } \\
\text { whose gestation was } \geq 3 \\
\text { and ratio of } \geq 0.2 \text {, the re } \\
<37 \text { wk had a } 17-O H P \text { l } \\
\text { result was considered to }\end{array}$ & $\begin{array}{l}\text { Minneso } \\
\text { rst-tier t } \\
\text { HP were } \\
\text { livided in } \\
\text { had a } 17 \\
\text { Jas consi } \\
\mathrm{f} \geq 6 \mathrm{ng} / \mathrm{n} \\
\text { ositive. }\end{array}$ & $\begin{array}{l}\text { ad Utah, the birt } \\
\text { In Sapporo, birt } \\
\text { ssed in the first- } t \\
\text { efore and after } \\
\text { P level of } \geq 4 \mathrm{ng} / \mathrm{r} \\
d \text { to be positive. I } \\
\text { a } 17-O H P \text { level c }\end{array}$ & $\begin{array}{l}\text { th weight-adjust } \\
\text { th weight- and g } \\
\text { tier test. Instead, } \\
37 \text { wk of gestati } \\
\mathrm{ml} \text { or a } 17-\mathrm{OHP} 1 \\
\text { If a neonate who } \\
\text { of } \geq 5 \mathrm{ng} / \mathrm{ml} \text { and }\end{array}$ & $\begin{array}{l}d \text { cutoff level of } \\
\text { stational week- } \\
\text { he cutoff levels } \\
\text { n. If a neonate } \\
\text { vel of } \geq 3 \mathrm{ng} / \mathrm{ml} \\
\text { e gestation was } \\
\text { tio of } \geq 0.2 \text {, the }\end{array}$ \\
\hline
\end{tabular}

be normal. One reason for the high false negative rate might be due to delayed rise of 17-OHP in some patients with classic 21-OHD $(33,34)$. In addition, the cutoff levels of 17-OHP and the ratio of (17-OHP +4AD)/cortisol in the second-tier test might be related.

Schwarz et al. (32) reported the results of LC-MS/MS as a second-tier test in MS for CAH from Utah, USA. Over a 13-mo period, 64,615 infants were screened by immunoassay in the first-tier test. A total of $2.6 \%(1,709)$ of the infants had a17-OHP level higher than the cutoff value in the first-tier test, and their filter papers were subjected to LC-MS/MS analysis in the secondtier test. The criteria for a positive second-tier test requiring a second blood sample and referral to a pediatric endocrinologist were the presence of both a 17-OHP level of greater than $12.5 \mathrm{ng} /$ $\mathrm{ml}$ and a ratio of (17-OHP+4AD) /cortisol greater than 1.0 (Table 1). As a result, 64 infants were considered to have a positive result in the second- tier test, and thus they required a second blood spot and referral to a pediatric endocrinologist. Among the infants who had a positive second-tier test, $80 \%(51 / 64)$ had a birth weight of $<2500 \mathrm{~g}$. Finally, among these 64 infants, 6 infants were diagnosed with 21-OHD. The FPR decreased from $2.6 \%$ to $0.09 \%$ using LC-MS/MS in the second-tier test, and the PPV improved from $0.4 \%$ to $9.4 \%$; however, the FPR was still high in the low birth weight infants.

In Sapporo Japan, steroid profiling from a blood spot by LC-MS/MS has been used as a second-tier test $(10,36)$. Fujikura et al. (36) reported the one-year results of MS for CAH using LC-MS/MS as a second-tier test since 2011. The two-tier protocol used in Sapporo was as follows (Table 1). When the 17-OHP level was $\geq$ $5.5 \mathrm{ng} / \mathrm{ml}$ by immunoassay in the first-tier test, the filter paper was automatically subjected to LC-MS/MS in a second-tier test. If an infant of $\geq 37$ weeks of gestational age showed either 1) a 
Table 2 Results of MS for CAH using LC-MS/MS as a second-tier test in Sapporo

\begin{tabular}{ccccc}
\hline Period & $\begin{array}{c}\text { Second-tier } \\
\text { test }\end{array}$ & Recall rate* & $\begin{array}{c}<37 \text { wk of } \\
\text { gestation }\end{array}$ & $\begin{array}{c}\geq 37 \text { wk of } \\
\text { gestation }\end{array}$ \\
\hline From 2009 to 2011 & HPLC & $0.65 \%$ & $7.9 \%$ & $0.09 \%$ \\
& & $(217 / 33,371)$ & $(190 / 33,371)$ & $(27 / 33,371)$ \\
From 2011 to 2012 & LC-MS/MS & $0.32 \%$ & $4.0 \%$ & $0.02 \%$ \\
& & $(93 / 28,790)$ & $(88 / 28,790)$ & $(5 / 28,790)$ \\
\hline
\end{tabular}

* Recall rate: an infant was considered to require recall if $2^{\text {nd }}$ filter-paper blood sample was required.

17-OHP level of $\geq 4 \mathrm{ng} / \mathrm{ml}$ or 2 ) a 17-OHP level of $\geq 3 \mathrm{ng} / \mathrm{ml}$ and a $(17-\mathrm{OHP}+4 \mathrm{AD}) /$ cortisol ratio of $\geq 0.2$ in the second-tier test, the result was considered to be positive, a second heel prick was requested, and the infant was referred to a pediatric endocrinologist. If an infant of $<37$ wk of gestational age showed either 1) a 17-OHP level of $\geq 6 \mathrm{ng} / \mathrm{ml}$ or 2 ) a $17-O H P$ level of $\geq 5 \mathrm{ng} /$ $\mathrm{ml}$ and a (17-OHP+4AD)/cortisol of $\geq 0.2$, the result was considered to be positive, a second heel prick was requested, and the infant was referred to a pediatric endocrinologist. During 2009 to 2011, the 17-OHP level was determined by HPLC in the second-tier test, and recall rate was $7.9 \%$ among neonates who were born at < 37 wk of gestation, whereas it was $0.09 \%$ among neonates who were born at $\geq 37$ wk of gestation (Table 2) (39). After the introduction of LC-MS/ $\mathrm{MS}$ as the second-tier test, the recall rate was $4.0 \%$ among neonates who were born at $<37 \mathrm{wk}$ of gestation, and the recall rate was $0.02 \%$ among neonates who were born at $\geq 37$ wk of gestation (Table 2). These data were obtained over a one-yr period, but the second-tier test using LC-MS/MS is likely to be useful to reduce the recall rate in term and preterm neonates.

LC-MS/MS is now used for neonatal screening of inborn errors of metabolism of amino acids and fatty acids in Japan (40). In most newborn screening laboratories, LC-MS/ $\mathrm{MS}$ is part of the basic equipment. However, LC-MS/MS for steroid analysis requires a higher level of laboratory expertise than an immunoassay. In addition, for steroid profiling from dried blood by LC-MS/MS, the equipment requires high sensitivity and more blood spots. Moreover, to determine amino acids and fatty acids and steroid profile simultaneously, further improvement of the LC-MS/MS equipment is needed. If these problems are solved in the future, steroid profiling by LC-MS/MS will be performed throughout Japan.

\section{Conclusion}

The low PPV of MS for $\mathrm{CAH}$ is a major challenge, and MS for $\mathrm{CAH}$ is still controversial worldwide. However, MS for $\mathrm{CAH}$ enables prevention of the development of salt-wasting symptoms and death in infants with undiagnosed 21-OHD. Several studies suggest that the use of LC-MS/MS as a second-tier test appears to be able to decrease the recall rate, although this method could not completely eliminate the FPR, especially in preterm infants.

\section{Acknowledgments}

We are grateful to Kaori Fujikura, Takuya Yamagishi, Yasuko Tagami, Jyunnji Hanai, Atsuhi Miyata, and Sapporo City Institute of Health for performing analysis of steroid profiles from blood spots. 


\section{References}

1. White PC, Speiser PW. Congenital adrenal hyperplasia due to 21-hydroxylase deficiency. Endocr Rev 2000;21: 245-91. [Medline]

2. Merke DP, Bornstein SR. Congenital adrenal hyperplasia. Lancet 2005;365: 2125-36. [Medline] [CrossRef]

3. Speiser PW, Azziz R, Baskin LS, Ghizzoni L, Hensle TW, Merke DP, et al. Endocrine Society Congenital adrenal hyperplasia due to steroid 21-hydroxylase deficiency: an Endocrine Society clinical practice guideline. J Clin Endocrinol Metab 2010;95: 4133-60. [Medline] [CrossRef]

4. Tajima T, Fujieda K, Nakae J, Toyoura T, Shimozawa K, Kusuda S, et al. Molecular basis of nonclassical steroid 21-hydroxylase deficiency detected by neonatal mass screening in Japan. J Clin Endocrinol Metab 1997;82: 2350-6. [Medline] [CrossRef]

5. Ishii T, Anzo M, Adachi M, Onigata K, Kusuda $\mathrm{S}$, Nagasaki K, et al. Guidelines for Diagnosis and treatment of 21-hydroxylase deficiency (2014 revision). Clin Pediatr Endocrinol 2015;24: 77-105. [CrossRef]

6. Auchus RJ. Management considerations for the adult with congenital adrenal hyperplasia. Mol Cell Endocrinol 2015;408: 190-7. [Medline] [CrossRef]

7. Reisch N. Substitution therapy in adult patients with congenital adrenal hyperplasia. Best Pract Res Clin Endocrinol Metab 2015;29: 33-45. [Medline] [CrossRef]

8. Kim MS, Merke DP. Cardiovascular disease risk in adult women with congenital adrenal hyperplasia due to 21-hydroxylase deficiency. Semin Reprod Med 2009;27: 316-21. [Medline] [CrossRef]

9. Han TS, Krone N, Willis DS, Conway GS, Hahner S, Rees DA, et al. United Kingdom Congenital adrenal Hyperplasia Adult Study Executive (CaHASE) Quality of life in adults with congenital adrenal hyperplasia relates to glucocorticoid treatment, adiposity and insulin resistance: United Kingdom Congenital adrenal Hyperplasia Adult Study Executive (CaHASE). Eur J Endocrinol 2013;168: 887-93. [Medline] [CrossRef]
10. Subbarayan A, Dattani MT, Peters CJ, Hindmarsh PC. Cardiovascular risk factors in children and adolescents with congenital adrenal hyperplasia due to 21-hydroxylase deficiency. Clin Endocrinol (Oxf) 2014;80: 471-7. [Medline] [CrossRef]

11. Bouvattier C, Esterle L, Renoult-Pierre P, de la Perrière AB, Illouz F, Kerlan V, et al. Clinical outcome, hormonal status, gonadotrope axis and testicular function in 219 adult men born with classic 21-hydroxylase deficiency. A French national survey. J Clin Endocrinol Metab 2015;100: 2303-13 [Epub ahead of print]. [Medline] [CrossRef]

12. White PC. Neonatal screening for congenital adrenal hyperplasia. Nat Rev Endocrinol 2009;5: 490-8. [Medline] [CrossRef]

13. Suwa S, Matsuura N, Kitagawa T, Igarashi Y, Tsumahara T. Results of neonatal mass screening for congenital adrenal hyperplasia (CAH) in Japan. Acta Paediatr Jpn 1988;30: 234-9 (in Japanese).

14. Tajima T, Fujikura K, Fukushi M, Hotsubo T, Mitsuhashi Y. Neonatal screening for congenital adrenal hyperplasia in Japan. Pediatr Endocrinol Rev 2012;10(Suppl 1): 72-8. [Medline]

15. Pang S, Hotchkiss J, Drash AL, Levine LS, New MI. Microfilter paper method for 17 alphahydroxyprogesterone radioimmunoassay: its application for rapid screening for congenital adrenal hyperplasia. J Clin Endocrinol Metab 1977;45: 1003-8. [Medline] [CrossRef]

16. Pang S, Clark A. Newborn screening, prenatal diagnosis, and prenatal treatment of congenital adrenal hyperplasia due to 21-hydroxylase deficiency. Trends Endocrinol Metab 1990;1: 300-7. [Medline] [CrossRef]

17. Balsamo A, Cacciari E, Piazzi S, Cassio A, Bozza D, Pirazzoli P, et al. Congenital adrenal hyperplasia: neonatal mass screening compared with clinical diagnosis only in the EmiliaRomagna region of Italy, 1980-1995. Pediatrics 1996;98: 362-7. [Medline]

18. Therrell BL Jr, Berenbaum SA, Manter-Kapanke V, Simmank J, Korman K, Prentice L, et al. Results of screening 1.9 million Texas newborns for 21-hydroxylase-deficient congenital adrenal hyperplasia. Pediatrics 1998;101: 583-90. 
[Medline] [CrossRef]

19. Mikami A, Fukushi M, Oda H, Fujita K, Fujieda K. Newborn screening for congenital adrenal hyperplasia in Sapporo City: sixteen years experience. Southeast Asian J Trop Med Public Health 1999;30(Suppl 2): 100-2. [Medline]

20. Van der Kamp HJ, Noordam K, Elvers B, Van Baarle M, Otten BJ, Verkerk PH. Newborn screening for congenital adrenal hyperplasia in the Netherlands. Pediatrics 2001;108: 1320-4. [Medline] [CrossRef]

21. Steigert M, Schoenle EJ, Biason-Lauber A, Torresani T. High reliability of neonatal screening for congenital adrenal hyperplasia in Switzerland. J Clin Endocrinol Metab 2002;87: 4106-10. [Medline] [CrossRef]

22. Gidlöf S, Wedell A, Guthenberg C, von Döbeln U, Nordenström A. Nationwide neonatal screening for congenital adrenal hyperplasia in sweden: a 26-year longitudinal prospective populationbased study. JAMA Pediatr 2014;168: 567-74. [Medline] [CrossRef]

23. Heather NL, Seneviratne SN, Webster D, Derraik JG, Jefferies C, Carll J, et al. Newborn screening for congenital adrenal hyperplasia in New Zealand, 1994-2013. J Clin Endocrinol Metab 2015;100: 1002-8. [Medline] [CrossRef]

24. Allen DB, Hoffman GL, Fitzpatrick P, Laessig R, Maby S, Slyper A. Improved precision of newborn screening for congenital adrenal hyperplasia using weight-adjusted criteria for 17-hydroxyprogesterone levels. J Pediatr 1997;130: 128-33. [Medline] [CrossRef]

25. Sarafoglou K, Gaviglio A, Hietala A, Frogner G, Banks K, McCann M, et al. Comparison of newborn screening protocols for congenital adrenal hyperplasia in preterm infants. J Pediatr 2014;164: 1136-40. [Medline] [CrossRef]

26. Coulm B, Coste J, Tardy V, Ecosse E, Roussey M, Morel Y, et al. DHCSF Study Group Efficiency of neonatal screening for congenital adrenal hyperplasia due to 21-hydroxylase deficiency in children born in mainland France between 1996 and 2003. Arch Pediatr Adolesc Med 2012;166: 113-20. [Medline] [CrossRef]

27. Wu JY, Sudeep, Cowley DM, Harris M, McGown IN, Cotterill AM. Is it time to commence newborn screening for congenital adrenal hyperplasia in Australia? Med J Aust 2011;195: 260-2. [Medline] [CrossRef]

28. Khalid JM, Oerton JM, Dezateux C, Hindmarsh PC, Kelnar CJ, Knowles RL. Incidence and clinical features of congenital adrenal hyperplasia in Great Britain. Arch Dis Child 2012;97: 101-6. [Medline] [CrossRef]

29. Lacey JM, Minutti CZ, Magera MJ, Tauscher AL, Casetta B, McCann M, et al. Improved specificity of newborn screening for congenital adrenal hyperplasia by second-tier steroid profiling using tandem mass spectrometry. Clin Chem 2004;50: 621-5. [Medline] [CrossRef]

30. Rossi C, Calton L, Hammond G, Brown HA, Wallace AM, Sacchetta P, et al. Serum steroid profiling for congenital adrenal hyperplasia using liquid chromatography-tandem mass spectrometry. Clin Chim Acta 2010;411: 222-8. [Medline] [CrossRef]

31. Janzen N, Sander S, Terhardt M, Steuerwald U, Peter M, Das AM, et al. Rapid steroid hormone quantification for congenital adrenal hyperplasia $(\mathrm{CAH})$ in dried blood spots using UPLC liquid chromatography-tandem mass spectrometry. Steroids 2011;76: 1437-42. [Medline] [CrossRef]

32. Schwarz E, Liu A, Randall H, Haslip C, Keune $\mathrm{F}$, Murray M, et al. Use of steroid profiling by UPLC-MS/MS as a second tier test in newborn screening for congenital adrenal hyperplasia: the Utah experience. Pediatr Res 2009;66: 230-5. [Medline] [CrossRef]

33. Sarafoglou K, Banks K, Gaviglio A, Hietala A, McCann M, Thomas W. Comparison of onetier and two-tier newborn screening metrics for congenital adrenal hyperplasia. Pediatrics 2012;130: e1261-8. [Medline] [CrossRef]

34. SeoJY, Park HD, Kim JW, Oh HJ, Yang JS, Chang YS, et al. Steroid profiling for congenital adrenal hyperplasia by tandem mass spectrometry as a second-tier test reduces follow-up burdens in a tertiary care hospital: a retrospective and prospective evaluation. J Perinat Med 2014;42: 121-7. [Medline] [CrossRef]

35. Higashi T, Nishio T, Uchida S, Shimada K, Fukushi M, Maeda M. Simultaneous determination of 17alpha-hydroxypregnenolone and 17alpha-hydroxyprogesterone in dried blood spots from low birth weight infants using LC- 
MS/MS. J Pharm Biomed Anal 2008;48: 177-82. [Medline] [CrossRef]

36. Fujikura K, Yamagishi T, Tagami Y, Hanai J, Takahashi H, Sasaki T, et al. Second-tier testing of neonatal screening for congenital adrenal hyperplasia using liquid chromatographytandem mass spectrometry. Journal of Japanese Society for Mass-screening 2013;23: 85-92 (in Japanese).

37. Varness TS, Allen DB, Hoffman GL. Newborn screening for congenital adrenal hyperplasia has reduced sensitivity in girls. J Pediatr 2005;147:
493-8. [Medline] [CrossRef]

38. White PC. Optimizing newborn screening for congenital adrenal hyperplasia. J Pediatr 2013;163: 10-2. [Medline] [CrossRef]

39. Morikawa S, Nakamura A, Fujikura K, Fukushi M, Hotsubo T, Miyata J, et al. Results from 28 years of newborn screening for congenital adrenal hyperplasia in sapporo. Clin Pediatr Endocrinol 2014;23: 35-43. [Medline] [CrossRef]

40. Yamaguchi S. Newborn screening in Japan: restructuring for the new era. Ann Acad Med Singapore 2008;37(Suppl): 13-5. [Medline] 